\title{
PENINGKATAN MOTIVASI DAN HASIL KARANGAN DESKRIPSI MELALUI STRATEGI PEMBELAJARAN CTL BERMUATAN KARAKTER
}

\author{
Khosyiatun \\ SD Negeri Sukoharjo 04 Kabupaten Sukoharjo \\ Email : Dra.khosyiatun@gmail.com
}

\begin{abstract}
Abstrak
Tujuan penelitian ini adalah mendiskripsikan peningkatan motivasi, hasil belajar dan perubahan nilai-nilai karakter dalam menulis karangan deskripsi pada peserta didik Kelas IV SD Negeri Sukoharjo 04 semester II tahun pelajaran 2016/2017 setelah penerapan strategi pembelajaran CTL bermuatan karakter. Penelitian dilaksanakan selama 6 bulan yaitu bulan Januari 2017 sampai dengan bulan Juni 2017. Subjek dalam penelitian adalah motivasi dan hasil belajar menulis karangan deskripsi peserta didik Kelas IV SD Negeri Sukoharjo 04 yang terdiri atas 21 peserta didik yaitu 6 laki-laki dan 15 perempuan. Jenis penelitian yang digunakan yaitu penelitian tindakan kelas (PTK) yang dilaksanakan dalam 2 siklus, setiap siklus terdiri dari 4 tahapan yaitu perencanaan, pelaksanaan, pengamatan, dan refleksi. Hasil penelitian melalui strategi pembelajaran CTL bermuatan karakter dapat meningkatkan motivasi belajar peserta didik dari kondisi awal ke siklus II dari kategori rendah menjadi tinggi. terdapat peningkatan nilai rata-rata motivasi belajar sebanyak 37, ada perubahan perilaku peserta didik_dari kondisi awal ke siklus II terjadi perubahan dari rata-rata nilai 1,52 kategori belum terlihat berubah menjadi nilai rataratanya 3,46 dalam kategori mulai berkembang terjadi perubahan 1,94 dan ada peningkatan nilai ketuntasan peserta didik dari 4 peserta didik (19\%) meningkat menjadi 21 peserta didik (100\%) bertambah 17 peserta didik (81\%). Nilai rata-rata kelas dari 57,4 menjadi 76,43, meningkat 19,03 .
\end{abstract}

Kata Kunci : Motivasi, Hasil Belajar, CTL Bermuatan Karakter

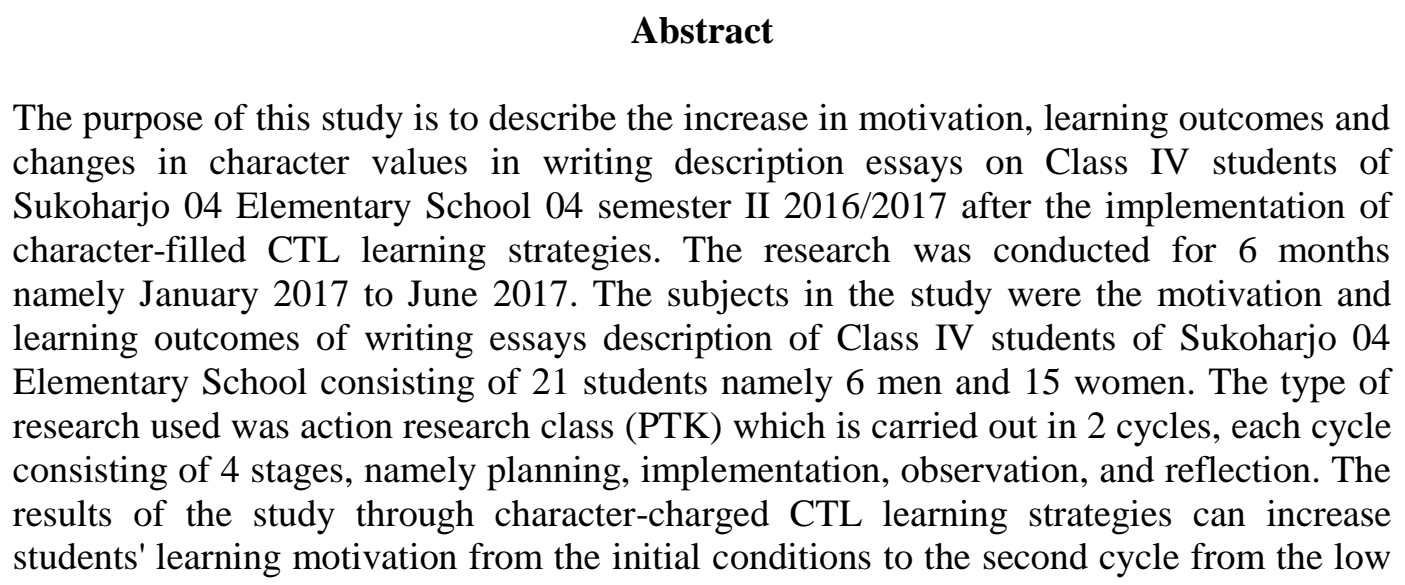


category to the high. there is an increase in the average value of learning motivation as much as 37, there is a change in behavior of students from the initial conditions to the second cycle there is a change from the average value of 1.52 categories have not been seen to change to an average value 3.46 in the category of developing changes occur 1.94 and there is an increase in the value of completeness of students from 4 students (19\%) increasing to 21 students (100\%) increasing by 17 students $(81 \%)$. The class average value from 57.4 to 76.43 , increased by 19.03 .

Keywords: Motivation, Learning Outcomes, Character-filled CTL

\section{PENDAHULUAN}

Salah satu jenis karangan yang diajarkan di tingkat sekolah dasar adalah jenis karangan deskripsi. Keterampilan menulis ini cenderung sulit dikuasai peserta didik. Hal ini disebabkan karangan deskripsi peserta didik harus dapat memberi gambaran mengenai sesuatu hal atau keadaan sehingga pembaca seolaholah melihat, mendengar, atau merasakan hal tersebut. Nurgiyantoro (2011) menjelaskan berdasarkan fakta karangan peserta didik hasil karangan mereka belum sesuai dengan harapan. Salah satu sebab mungkin adalah pemberian tugas mengarang itu sendiri yang tidak jelas dan tidak memaksa peserta didik mencari rujukan. Jadi mereka hanya menulis hal-hal yang terlintas di kepalanya.

Berdasarkan hasil angket motivasi belajar peserta didik kelas IV SD Negeri Sukoharjo 04 semester II tahun pelajaran 2016/2017 masih rendah. Masalah tersebut menyebabkan hasil tes menulis karangan juga masih rendah dari 21 peserta didik yang mendapat nilai tuntas di atas KKM 64 hanya ada 4 (19\%) peserta didik dan yang mendapat nilai di bawah KKM ada 17 (81\%) peserta didik, dengan nilai rata-rata kelas 57,4. Hasil karangan peserta didik belum sistematis pokok pikiran yang disusun masih tumpang tindih. Kalimat-kalimat dalam paragraf yang disusun masih kacau, tidak pas, sering terjadi pengulangan kata dan kalimat satu dengan kalimat lain dan satu paragraf tidak nyambung.

Berdasarkan kondisi di atas perlu adanya solusi untuk memecahkan masalah. Salah satunya adalah penerapan strategi pembelajaran CTL (Contextual Teaching And Learning) bermuatan karakter. Diharapkan setelah adanya penerapan strategi pembelajaran CTL (Contextual Teaching And Learning) bermuatan karakter, motivasi dan hasil belajar menulis karangan deskripsi peserta 
didik meningkat. Motivasi belajar peserta didik meningkat dari kategori rendah menjadi tinggi. Persentase kriteria ketuntasan minimal (nilai KKM 64) minimal meningkat menjadi $78 \%$ dan rata-rata untuk mata pelajaran bahasa Indonesia minimal meningkat menjadi 65. prosentase nilai-nilai karakter peserta didik yang meliputi: kerja keras, rasa ingin tahu, kreatif, mandiri, dan peduli lingkungan sosial meningkat menjadi $70 \%$ dengan kategori baik.

Muslich (2009) menjelaskan bahwa pembelajaran kontekstual atau Contextual Teaching and Learning (CTL) adalah konsep belajar yang membantu guru mengaitkan antara materi pembelajaran dengan dunia nyata peserta didik, dan mendorong peserta didik membuat hubungan antara pengetahuan yang dimiliki dengan penerapannya dalam kehidupan mereka sehari-hari. Strategi pembelajaran CTL Bermuatan karakter dipilih karena dalam sebuah strategi belajar yang tidak mengharuskan peserta didik menghafal fakta-fakta, tetapi sebuah strategi yang mendorong peserta didik mengkontruksikan pengetahuan dibenak mereka sendiri. Melalui strategi $C T L$, peserta didik diharapkan belajar melalui "mengalami”, bukan menghafal. Konsep dasar CTL bermuatan karakter adalah "memasukan" nilai-nilai karakter ke dalam CTL, sehingga ketika guru mengajar dengan menggunakan metode $C T L$, maka secara otomatis guru tersebut menanamkan nilai-nilai karakter kepada peserta didik (Suyadi, 2013).

Untuk menciptakan suasana belajar yang menyenangkan serta serius tapi santai, menciptakan suasana belajar dari pasip ke aktif, dari kaku menjadi gerak, dan jadi jenuh menjadi riang peneliti menggunakan icebreaker dalam pembelajaran. Icebreaker dalam pembelajaran dapat diartikan sebagai pemecah situasi kebekuan pikiran atau fisik siswa dengan maksud membangun suasana belajar yang dinamis, penuh semangat, dan antusias (Sunarto,2012). Icebreaker yang dgunakan dalam penelitian ini direncanaakan dipilih dengan jenis tepuk tangan dan yel-yel.

Alasan memilih strategi pembelajaran CTL bermuatan karakter dalam pembelajaran bahasa Indonesia khususnya mengarang diharapkan menjadi wahana penanaman nilai-nilai karakter sesuai dengan tingkat perkembangan peserta didik sekolah dasar. Tujuan penelitian adalah sebagai berikut: 
Mendeskripsikan peningkatan motivasi menulis karangan deskripsi pada peserta didik Kelas IV SD Negeri Sukoharjo 04 semester II tahun pelajaran 2016/2017 setelah menerapan strategi pembelajaran CTL bermuatan karakter; Mendeskripsikan perubahan perilaku peserta didik Kelas IV SD Negeri Sukoharjo 04 semester II tahun pelajaran 2016/2017 setelah menerapan strategi pembelajaran CTL bermuatan karakter; dan Mendeskripsikan peningkatan hasil belajar menulis karangan deskripsi pada peserta didik Kelas IV SD Negeri Sukoharjo 04 semester II tahun pelajaran 2016/2017 setelah menerapan strategi pembelajaran CTL bermuatan karakter.

Tugas guru adalah membangkitkan motivasi peserta didik sehingga mau melakukan belajar. Untuk membangkitkan motivasi belajar peserta didik guru hendaknya dapat menumbuhkan motivasi sebagai berikut: kompetisi (persaingan): Guru berusaha menciptakan persaingan diantara siswanya untuk meningkatkan prestasi belajarnya,berusaha memperbaiki hasil prestasi yang telah dicapai sebelumnya dan mengatasi prestasi orang lain; Place making (membuat tujuan sementara atau dekat): Pada awal kegiatan belajar mengajar,guru hendaknya terlebih dahulu menyampaikan kepada siswa tujuan yang akan dicapainya sehingga dengan demikian siswa berusaha untuk mencapai tujuan tersebut; Tujuan yang jelas; Motif mendorong individu untuk mencapai tujuan; Kesempurnaan untuk sukses: kesuksesan dapat menimbulkan rasa puas, kesenangan dan kepercayaan terhadap diri sendiri, sedangkan kegagalan akan membawa efek sebaliknya; Minat yang besar: motif akan timbul jika individu memiliki minat yang besar; Dan mengadakan penilaian atau tes: pada umumnya semua siswa mau belajar dengan tujuan memperoleh nilai yang baik.(Daryanto, 2012).

Donald (dalam Yamin, 2007) mendifinisikan motivasi adalah perubahan energi dalam diri (pribadi) seseorang yang ditandai dengan timbulnya perasaan dan reaksi untuk mencapai tujuan. Sedangkan menurut Daryanto (2012) motivasi adalah suatu proses untuk menggiatkan motif-motif menjadi perbuatan atau tingkah laku untuk memenuhi kebutuhan dan mencaai tujuan atau keadaan dan 
kesiapan dalam diri individu yang mendorong tingkah lakunya berbuat sesuatu dalam mencaai tujuanya.

Motivasi belajar peserta didik memiliki pengaruh yang cukup kuat terhadap keberhasilan proses maupun hasil belajar peserta didik. Motivasi merupakan daya penggerak dala diri seseorang untuk melakukan aktivitasaktivitas guna mencapai tujuan tertentu Widoyoko (2012). Hakikat motivasi belajar adalah dorongan internal dan eksternal pada peserta didik yang sedang belajar untuk mengadakan perubahan perilaku. Motivasi belajar adalah proses yang memberikan semangat belajar, arah, dan kegigihan perilaku. Artinya, perilaku yang termotivasi adalah perilaku yang penuh energi, terarah dan bertahan lama. Salah satu indikator kualitas pembelajaran adalah motivasi belajar dari peserta didik. Motivasi belajar memegang peranan yang penting dalam membeir gairah, semaangat dan rasa senang dalam belajar sehingga peserta didik yang mempunyai motivasi tinggi mempunyai energi yang banyak untuk melaksanakan kegiatan belajar yang pada akhirnya akan mampu memperoleh prestasi yang lebih baik.

Ahmadi (2011) menjelaskan motivasi intrinsik dan ekstrinsik, dengan lebih mengembngkan motivasi instrinsik siswa agar proses belajar yang ditekuni muncul berdasarkan, minat dan inisiatif sendiri bukan karena dorongan lingkungan atau orang lain. Belajar siswa akan meningkat karena ditunjang oleh pendekatan belajar yang dilakukan guru lebih dipusatkan kepada siswa, guru tidak hanya menyuapi atau menuangkan dalam ember, tetapi menghidupkan api yang menerangi sekelilingnya, dan bersikap positip kepada siswa.

Motivasi yang tinggi dapat menggiatkan aktifitas belajar siswa. Motivasi yang tinggi tersebut dapat ditemukan dalma sifat dan perilaku siswa antara lain : adanya kualitas keteribatan siswa dalam belajar yang sangat tinggi; adanya perasaan dan keterlibatan afektif siswa yang tinggi dalam belajar; dan adanya upaya siswa untuk senantiasa memelihara atau menjaga agar senantiasa memiliki motivasi beajar yang tinggi (Amri, 2013). 
Indikator motivasi belajar menurut Hamzah (dalam Suprijono, 2009) dapat diklasifikasikan sebagai berikut: (1) adanya hasrat dan keinginan berhasil; (2) adanya dorongan dan kebutuhan dalam belajar; (3) adanya harapan dan cita-cita masa depan; (4) adanya penghargaan dalam belajar; dan (5) adanya lingkungan belajar yang kondusif sehingga memungkinkan peserta didik dapat belajar dengan baik. sedangkan Ciri-ciri motivasi berprestasi menurut Widoyoko (2012) ada empat, yaitu: (1) berorientasi pada keberhasilan; (2) bertanggung jawab; (3) inovatif; dan (4) mengantisipasi kegagalan.

Motivasi Merupakan kondisi yang menimbulkan perilaku, mengarahkan perilaku, atau mempertahankan intensitas perilaku. Motivasi belajar dapat dilakukan dengan meningkatkan perhatian (attention), relevansi (relevance), kepercayaan diri (confidence), dan kepuasan (satisfaction) peserta didik dalam belajar (Abdullah, 2015). Strategi untuk meningkatkan perhatian peserta didik yaitu dengan 1) menggunakan metode instruksional yang bervariasi, 2) menggunakan variasi media (transparasi, audio-video, dan sebagainya) untuk melengkapi pembelajaran, 3) menggunkan humor pada saat yang tepat, 4) menggunakan peristiwa nyata sebagai contoh untuk memperjelas konsep, 5) menggunakan teknik bertanya untuk melibatkan peserta didik.

Berdasarkan penjelasan di atas motivasi yang berkaitan dengan tujuan belajar, motivasi mempunyai fungsi mendorong peserta didik untuk berbuat, menentukan arah kegiatan pembelajaran yakni kearah tujuan belajar yang hendak dicapai dan menyeleksi kegiatan pembelajaran untuk menentukan kegiatankegiatan apa yang harus dikerjakan. Belajar merupakan perubahan perilaku seseorang melalui latihan dan pengalaman, motivasi akan memberi hasil yang lebih baik terhadap perbuatan yang dilakukan seseorang. Hasil belajar dapat diukur dalam bentuk perubahan pengetahuan, sikap, dan keterampilan, perubahan yang lebih baik dibandingkan sebelumnya, misalnya dari tidak bisa menjadi bisa, dari tidak santun menjadi santun. 
Hasil belajar adalah kemampuan-kemampuan yang dimiliki peserta didik setelah menerima pengalaman belajarnya (Sudjana, 2002). Ada tiga macam hasil belajar mengajar: (1) keterampilan dan kebiasaan; (2) pengetahuan dan pengarahan; (3) sikap dan cita-cita. Sedangkan menurut Suprijono (2009) hasil belajar adalah pola-pola perbuatan, nilai-nilai, pengertian-pengertian, sikap-sikap, apresiasi dan keterampilan.Menurut teori Bloom, penilaian haruslah mencakup ranah kognitif, afektif dan psikomotorik (dalam Nurgiyantoro 2011). Hasil belajar harus menunjukkan suatu perubahan tingkah laku atau perolehan perilaku yang baru dari siswa yang bersifat menetap, fungsional, positif, dan disadari (Anitah, 2008). Menurut Suprijono (2009) menjelaskan pengertian hasil belajar adalah pola-pola perbuatan ,nilai-nilai, pengertian-pengertian , sikap-sikap, apresiasi dan keterampilan.

Bloom dalam Anitah (2008) menjelaskan bahwa hasil belajar mencakup aspek kognitif, afektif, dan psikomotor. Aspek kognitif berkaitan dengan hasil berupa pengetahuan, kemampuan dan kemahiran intelektual. Aspek kognitif mencakup kategori pengetahuan, pemahaman, penerapan, analisis, sintesis dan penilaian. Aspek afektif berkaitan dengan perasaan, sikap, minat, dan nilai. Aspek afektif mencakup penerimaan, penilaian, pengorganisasian, dan pembentukan pola hidup atau karakterisasi. Aspek psikomotor berkaitan dengan hasil belajar yang menyangkut gerakan-gerakan otot psikomotor. Sebagai petunjuk bahwa siswa telah memperoleh keterampilan aspek psikomotor, siswa dapat melakukan aktivitas menulis, dan mengucapkan lafal bahasa.

Sudjana (2010) menjelaskan hasil belajar adalah kemampuan-kemampuan yang dimiliki siswa setelah ia menerima pengalaman belajarnya. Senada dengan pendapat Kingsley dalam Sudjana (2010) membagi tiga macam hasil belajar, yakni keterampilan dan kebiasaan, pengetahuan dan pengertian, sikap dan citacita. Kebiasaan adalah perpadauan antara pengetahuan, keterampilan dan keinginan. Pengetahuan berarti memahami apa yang harus diperbuat. Keterampilan berarti mengerti bagaimana melakukannya. Pengertian adalah suatu pernyataan mengenai ciri-ciri penting suatu hal dan biasanya lebih kompleks dari 
arti atau makna suatu hal.Sikap adalah keadaan diri dalam manusia yang menggerakkan untuk bertindak atau berbuat dalam kegiatan sosial dengan perasaan tertentu di dalam menanggapi obyek situasi ataukondisi di lingkungan sekitarnya.Sedangkan cita-cita adalah sesuatu yang ingin kita capai disertai perencanaan dan tindakan kita untuk mencapainya.

Dari beberapa pengertian tersebut, maka dapat disimpulkan bahwa hasil belajar adalah perubahan perilaku yang diperoleh siswa setelah melakukan kegiatan belajar yang bersifat menetap, fungsional, positif, dan disadari. Perubahan perilaku tersebut tergantung pada apa yang telah dipelajari oleh siswa. Apabila siswa mempelajari tentang keterampilan, maka perubahan perilaku yang diperoleh berupa penguasaan keterampilan. Jika siswa mempelajari sikap, maka hasil belajar yang diharapkan muncul adalah perubahan sikap.

Keraf (1982) menjelaskan deskripsi atau pemberian merupakan sebuah bentuk tulisan yang bertalian dengan usaha para penulis untuk memberikan perincian-perincian dari objek yang sedang dibicarakan. Kata deskripsi berasal dari kata latin describe yang berarti menulis tentang, atau membeberkan sesuatu hal.

Dari uraian tersebut di atas dapat diambil suatu pengertian bahwa menulis karangan deskripsi merupakan usaha untuk menggambarkan perasaan, situasi atau wujud suatu objek yang pernah dilihat, didengar, dirasakan atau dialami seseorang dengan menggunakan kata-kata yang dituangkan dalam bentuk tulisan. Tulisan deskripsi dikatakan baik apabila mampu melukiskan suatu objek sejelas-jelasnya. Dalam hal ini seluruh pancaindera penulis harus aktif. Sesuatu yang dideskipsikan harus tersaji secara gamblang, hidup, dan tepat, serta menghindari pernyataan umum yang tidak terinci.

Suparno (2008) menjelaskan langkah-langkah menulis karangan deskripsi yaitu: (a) menentukan apa yang akan dideskripsikan: apakah akan mendeskripsikan orang atau tempat?; (b) merumuskan tujuan pendeskripsian: apakah deskripsi dilakukan sebagai alat bantu karangan narasi, eksposisi, argumentasi, atau persuasi?; (c) menetapkan bagian yang akan dideskripsikan: 
kalau yang dideskripsikan orang, apakah yang dideskripsikan itu ciri-ciri fisik, watak, gagasannya, atau benda-benda disekitar tokoh? Kalau yang dideskripsikan tempat, apakah yang akan dideskrisikan keseluruhan tempat atau hanya bagianbagian tertentu saja yang menarik?; dan (d) memerinci dan mensistematiskan halhal yang menunjang kekuatan bagian yang akan dideskripsikan: hal-hal apa saja yang akan ditampilkan untuk membantu memunculkan kesan dan gambaran kuat mengenai sesuatu yang dideskripsikan? Pendekatan apa yang akan digunakan penulis?.

Menurut Mueller (dalam Nurgiyantoro, 2011) penilaian yang dilakukan terhadap karangan peserta didik dapat dilakukan dengan penilaian holistik atau analitis ke dua tehnik penilaian tersebut baik holistik dan analitik, sama-sama dapat mempergunakan rubrik penilaian. Penilaian holistik dimaksudkan sebagai cara penilaian hasil karangan yang bersifat menyeluruh dan sekaligus tanpa dirinci ke dalam komponen pendukungnya. Artinya, menilai sebuah hasil karangan peserta didik secara keseluruhan, dibaca dari awal hingga akhir, dan setelah selesai langsung diberi skor. Skor itu mewakili secara keseluruhan karangan itu tanpa informasi skor perkomponen karangan. Bahkan, tidak jarang guru tidak membaca keseluruhan karangan, jadi hanya sebagian-sebagian, dan langsung membubuhkan skor. Dengan demikian, sebenarnya penilaian yang menyeluruh tersebut hanya berdasarkan kesan yang diperoleh dari membaca karangan secara selintas.

Menurut Suprijono (2009) pembelajaran kontekstual atau Contextual Teaching and Learning (CTL) merupakan konsep yang membantu guru mengaitkan antara materi yang diajarkan dengan situasi dunia nyata yang mendorong peserta didik membuat hubungan antara pengetahuan yang dimilikinya dengan penerapan dalam kehidupan mereka sebagai anggota keluarga dan masyarakat. Pembelajaran kontekstual merupakan prosedur pendidikan yang bertujuan membantu peserta didik memahami makna bahan pelajaran yang mereka pelajari dengan cara menghubungkanya dengan konteks kehidupan mereka sendiri dalam lingkungan sosial dan budaya masyarakat. 
Daryanto (2012) menyatakan pembelajaran kontekstual (Contextual Teaching and Learning) sebagai konsep belajar yang membantu guru mengaitkan antara materi yang diajarkan dengan situasi dunia nyata siswa dan mendorong siswa membuat hubungan antara pengetahuan yang dimilikinya dengan penerapannya dalam kehidupan mereka sehari-hari, dengan melibatkan tujuh komponen, yakni: (1) kontruktivisme (constuctivism); (2) bertanya (questioning); (3) menemukan (inquiri); (4) masyarakat belajar (learning community); (5) permodelan (modeling); (6) refleksi (reflection); dan (7) penilaian sebenarnya (authentic assessment).

Menurut pandangan CTL sebuah proses pembejalaran harusnya : 1) menekankan pada pemecahan masalah (berbasis Inquiry); 2) menyadari kebutuhan akan pengajaran dan pembelajaran yang terjadi dalam berbagai konteks seperti dirumah, masyakarakat, dan pekerjaan; 3) mengarahkan siswa agar dapat memonitor dan mengarahkan pembelajaran mereka sendiri sehingga menjadi pembelajra yang madiri; 4) mengaitkan pengajaran pada konsteks kehidupn siswa yang berda-beda; 5) mendorong siwa untuk belajar dari sesama teman dan belajar bersama; dan 6) menerpakan penilaian autentik (Amri, 2013)

Pembelajaran dengan menerapkan pendekatan kontekstual harus sudah tercermin dari perencanaan pembelajaran, pelaksanaan pembelajaran sampai dengan penilaian pembelajaran. Ismawati (2011) menjelaskan bahwa ada beberapa hal yang harus diperhatikan guru sebelum menyusun rencana pembelajaran agar efektif yaitu: (1) guru harus tahu benar tujuan yang hendak dicapai dalam mengajar. Tujuan pengajaran ini harus dirumuskan seoperasional mungkin agar hasil pengajaran mudah dievaluasi; (2) guru harus memutuskan dan menetapkan tingkah laku yang akan dimiliki dan diperlihatkan murid setelah berakhirnya satu periode belajar-mengajar; (3) guru harus menetapkan satu strategi pengajaran, menyangkut penggunaan metode dan media sebagai prasyarat pencapaian tujuan PBM; dan (4) guru harus mempersiapkan alat-alat evaluasi untuk mengetahui seberapa jauh tercapainya tujuan. 
Dalam pembelajaran keterampilan menulis dapat dilakukan secara aktif dan kreatif untuk memotivasi dan memberikan inspirasi kepada para siswa untuk menulis. Rohmadi (2009) menjelaskan pengajaran menulis berbasis Pembelajaran Aktif Inovatif Kreatif dan Menyenangkan (PAIKEM) dapat dilakukan dengan urutan sebagai berikut: (1) penjelasan tujuan pembelajaran keterampilan menulis kepada para siswa; (2) mempersiapkan media pembelajaran (topik-topik) yang akan digunakan bahan untuk berlatih keterampilan menulis untuk para siswa; (3) para siswa diminta berpasangan membentuk kelompok 4-5 siswa kemudian diberi nama kelompok, atau bisa juga secara individu bergantung pada topiknya; (4) kemudian masing-masing kelompok diberi topik untuk diamati dan dijadikan inspirasi; (5) kemudian para siswa atau secara berurutan kelompok-kelompok tadi mempersentasikan hasil kelompoknya, (6) mintalah satu kelompok untuk mengomentari atau menanggapi kelompok lain; (7) perhatikan anak-anak yang tidak ada respon atau apresiasi dalam menulis atau diam saja.,teliti ada masalah apa anak tersebut tidak mau menulis; dan (8) kemudian berikan simpulan, penguatan, refleksi, dan tidak lanjut.

Penerapan pendekatan $C T L$ dalam pembelajaran menulis dilakukan dengan mengembangkan pemikiran bahwa pembelajaran akan lebih bermakna apabila tujuh komponen $C T L$ diterapkan secara nyata selama proses pembelajaran menulis berlangsung yaitu melalui inkuiri, bertanya, kontruktivisme, masyarakat belajar, pemodelan, penilaian otentik, dan refleksi. Ismawati (2011) menjelaskan langkah-langkah penerapan pembelajaran menulis dengan pendekatan kontekstual yaitu: 1) mengamati objek yang akan ditulis, 2) mencatat unsur-unsur penting dari objek yang akan ditulis, 3) menyusun kerangka tulisan, 4) menulis sesuai objek yang akan diamati dan kerangka tulisan yang telah disusun, 5) membentuk kelompok untuk diskusi, 6) mendiskusikan hasil tulisan, dan 7) memperbaiki hasi tulisan berdasarkan hasil diskusi dan arahan dosen atau guru.

Terdapat enam nilai karakter dari 18 nilai karakter yang dicanangkan Kemendikbud yang dapat ditransmisikan melalui strategi pembelajaran 
kontekstual, diantaranya adalah: kerja keras, rasa ingin tahu, kreatif, mandiri, tanggung jawab, dan peduli lingkungan sosial.

Suyadi (2013) menjelaskan prosedur pelaksanaan CTL bermuatan karakter guru harus melakukan langkah-langkah sebagai berikut: Tahap pendahuluan: (1) guru menjelaskan kompetensi yang harus dicapai serta memanfaatkan dari proses pembelajaran dan pentingnya materi pelajaran yang akan dipelajari; (2) guru menjelaskan prosedur pembelajaran kontekstual yang akan diterapkan kepada peserta didik; dan (3) peserta didik dibagi ke dalam kelompok kecil, masingmasing kelompok terdiri dari 4-6 peserta didik.

Tahap ke dua adalah kegiatan inti, tugas yang harus dilakukan oleh peserta didik adalah: (1) berkunjung ke perpustakaan untuk mencari sumber-sumber bacaan yang dibutuhkan; (2) semua kelompok mencatatat hasi pekerjaan lapangan sesuai dengan ketentuan yang telah dibuat sebelumnya; (3) setelah selesai dari lapangan, maka peserta didik kembali ke dalam kelas untuk mendiskusikan temuan lapangan mereka bersama-sama sesuai kelompoknya masing-masing, masing-masing kelompok melaporkan hasil diskusi kepada kelompok yang lain dan setiap kelompok menjawab setiap pertanyaan yang di ajukan oleh kelompok lain. Pada tahap terakhir adalah penutup, peserta didik dibantu menyimpulkan hasil observasi atau wawancara dan diskusi kelas

Menurut Suyadi (2013) keunggulan pembelajaran CTL bermuatan karakter sebagai berikut : 1) melalui $C T L$ bermuatan karakter materi yang dipelajari peserta didik tidak lagi tergantung sepenuhnya pada guru, tetapi dapat menambah kepercayaan kemampuan berpikir sendiri (mandiri), menggali informasi dari berbagai sumber (rasa ingin tahu) dan belajar dari peserta didik yang lain; 2) Melalui CTL bermuatan karakter, ide atau gagasan peserta didik dapat dikembangkan dengan kata-kata secara verbal dan membandingkannya dengan ide-ide orang lain; 3) CTL bermuatan karakter dapat membantu peserta didik untuk respek pada orang lain dan menyadari akan segala keterbatasannya, serta menerima segala perbedaan (toleransi), baik dalam satu kelompok maupun 
kelompok lain; 4) CTL bermuatan karakter dapat membantu setiap peserta didik untuk lebih bertanggung jawab dalam belajar mandiri maupun kelompok; 5) $C T L$ bermuatan karakter merupakan strategi yang cukup ampuh untuk meningkatkan prestasi akademik sekaligus kemampuan sosial, termasuk mengembangkan rasa harga diri, hubungan interpersonal yang positif dengan peserta didik yang lain, mengembangkan ketrampilan mengatur waktu dan sikap positif terhadap sekolah; 6) CTL bermuatan karakter dapat mengembangkan kemampuan peserta didik untuk menguji ide dan pemahamannya sendiri dengan cara menerima umpan balik. Peserta didik dapat mempraktikkan pemecahan masalah tanpa takut membuat kesalahan, karena keputusan yang dibuat adalah tanggung jawab bersama; 7) $C T L$ bermuatan karakter dapat meningkatkan kemampuan peserta didik menggunakan informasi dan kemampuan belajar abstrak menjadi nyata atau konkret; 8) CTL bermuatan karakter dapat mengkondisikan guru-peserta didik maupun sesama peserta didik selama proses pembelajaran sehingga dapat meningkatkan motivasi dan memberikan rangsangan untuk berpikir lebih keras. Hal ini berguna untuk proses pendidikan jangka panjang.

Berdasarkan penjelasan di atas dirumuskan hipotesis tindakan sebagai berikut: 1)Melalui penerapan strategi pembelajaran CTL bermuatan karakter dapat meningkatkan motivasi menulis karangan deskripsi pada peserta didik kelas IV SD Negeri Sukoharjo 04 semester II tahun pelajaran 2016/2017; 2)Melalui penerapan strategi pembelajaran $C T L$ bermuatan karakter dapat merubah perilku ke arah positif peserta didik kelas IV SD Negeri Sukoharjo 04 semester II tahun pelajaran 2016/2017; dan 3)Melalui penerapan strategi pembelajaran CTL bermuatan karakter melalui dapat meningkatkan hasil belajar menulis karangan deskripsi pada peserta didik kelas IV SD Negeri Sukoharjo 04 semester II tahun pelajaran 2016/2017.

\section{METODE PENELITIAN}


Penelitian dilaksanakan selama 6 bulan yaitu Januari 2017 sampai dengan Juni 2017. Penelitian dilaksanakan 2 siklus, siklus I dilaksanakan 3 kali pertemuan, pertemuan pertama dilaksanakan Senin, 6 Maret 2017, pertemuan ke dua Selasa, 7 Maret 2017 dan pertemun ke tiga Kamis, 9 Maret 2017. Siklus II dilaksanakan 3 kali pertemuan, pertemuan pertama dilaksanakan Senin, 20 Maret 2017, pertemuan ke dua Selasa, 21 Maret 2017 dan pertemuan ketiga Kamis, 23 Maret 2017. Penelitian dilaksanakan di Kelas IV SD Negeri Sukoharjo 04, UPTD Pendidikan Kecamatan Sukoharjo kabupaten Sukoharjo Provinsi Jawa Tengah.Subjek penelitian adalah motivasi dan hasil belajar menulis karangan deskripsi peserta didik Kelas IV SD Negeri Sukoharjo 04 yang terdiri atas 21 peserta didik yaitu 6 laki-laki dan 15 perempuan.

Sumber data ada dua yaitu,data primer tentang motivasi belajar berupa hasil angket yang diisi peserta didik, sedangkan data primer tentang hasil belajar berupa nilai ulangan harian. Sumber data selain dari penelitian merupakan sumber data skunder yaitu data hasil pengamatan perubahan perilaku peserta didik yang dilakukan dengan koloborasi dengan teman sejawat.

Teknik pengumpulan data dalam penelitian ini adalah menggunakan teknik dokumen, teknik tes, dan teknik non tes. Teknik dokumen, digunakan untuk mengetahui data kondisi awal peserta didik sebelum dilakukan penelitian yaitu nilai ulangan harian sebelumnya. Alatnya berupa daftar nilai/ laporan penilaian, pengolahan dan analisis hasil belajar peserta didik.Teknis tes, yaitu dengan tes tertulis yang digunakan untuk mendapatkan data hasil belajar menulis karangan deskripsi. Alatnya berupa butir soal. Teknis non tes, yaitu berupa angket yang digunakan untuk mengetahui tentang peningkatan motivasi peserta didik yang berupa daftar pertanyaan. Tehnik observasi digunakan untuk mengumpulkan nilai karakter peserta didik yang berupa lembar pengamat berupa skala sikap skala sikap, catatan harian guru dan siswa dan lembar pengamatan diskusi dan lembar observasi guru digunakan untuk mengamati keterampilan dasar mengaajar guru yang berupa lembar pengamatan.

Untuk memperoleh data yang valid, motivasi belajar peserta didik yang berupa angket yang divalidasi adalah istrumen tes yang berupa pernyataan dengan 
content validity diperlukan kisi-kisi pernyataan yang meliputi ciri-ciri motivasi belajar (orientasi keberhasilan, antisipasi kegagalan, inovasi dan tanggung jawab). Data yang berupa angka (data kuantitatif menggunakan analisis deskriptif komparatif yaitu membandingkan hasil angket siklus I, dan siklus II kemudian direfleksi).Hasil belajar menulis deskripsi yang berupa nilai karangan deskripsi yang divalidasi adalah istrumen tes yang berupa butir soal dengan content validity diperlukan kisi-kisi soal. Data yang berupa angka (data kuantitatif menggunakan analisis deskriptif komparatif yaitu membandingkan nilai karangan deskripsi kondisi awal, nilai tes siklus I, dan nilai tes siklus II kemudian direfleksi).Nilainilai karakter peserta didik dianalisis menggunakan analisis diskriptif kualitatif dengan membandingkan siklus I dan siklus II, kemudian direfleksi.

Data kualitatif hasil pengamatan proses pembelajaran dianalisis menggunakan analisis diskriptif kualitatif dengan membandingkan siklus I dan siklus II. Sedangkan data yang berupa angka (data kuantitatif) dari hasil belajar dan motivasi belajar peserta didik dianalisis menggunakan diskriptif komparatif yaitu membandingkan nilai tes kondisi awal, nilai tes setelah siklus I dan nilai tes setelah siklus II, kemudian direfleksi.

Indikator keberhasilan kinerja dalam penelitian tindakan kelas adalah: meningkatnya motivasi belajar peserta didik dari kategori rendah menjadi tinggi. Meningkatnya hasil belajar persentase kriteria ketuntasan minimal (nilai KKM 64) dari kondisi awal 19\% menjadi 78\% dan rata-rata kelas kondisi awal 57,4 minimal meningkat menjadi 65.Adanya perubahan sikap nilai-nilai karakter peserta didik meliputi: kerja keras, rasa ingin tahu, kreatif, mandiri, tanggung jawab dan peduli lingkungan sosial dari kategori belum terlihat minimal berubah menjadi mulai berkembang.

Penelitian ini menggunakan penelitian tindakan kelas (PTK). Penelitian ini dilaksanakan dalam 2 siklus, setiap siklus terdiri dari 4 tahapan yaitu tahap perencanaan, tahap tindakan, tahap pengamatan/observasi dan refleksi. Prosedur ini secara garis besar dapat dijelaskan dengan gambar skema sebagai berikut. 


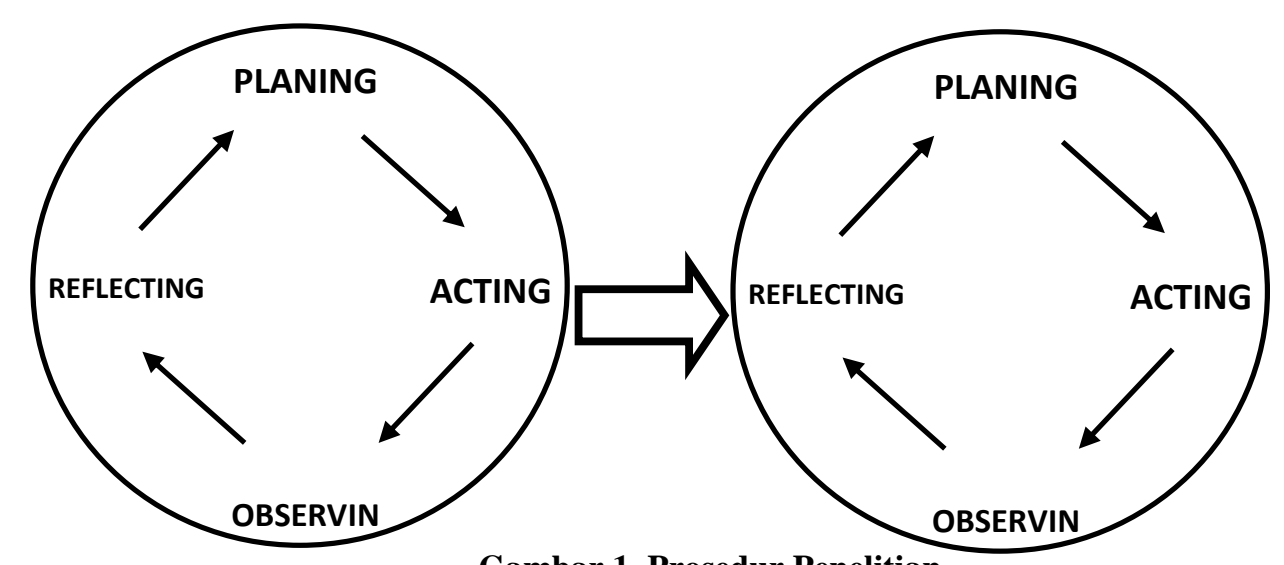

Gambar 1. Prosedur Penelitian

\section{HASIL DAN PEMBAHASAN}

\section{a. Hasil Penelitian}

Berdasarkan hasil deskripsi kondisi awal, siklus I dan siklus II, yang dibahas meliputi: (1) motivasi belajar; (2) perubahan perilaku peserta didik; (3) proses pembelajaran guru; dan (4) hasil mengarang peserta didik.

1) Motivasi Belajar Peserta Didik Antar Siklus

Tabel 1 menunjukkan bahwa dengan penerapan strategi pembelajaran CTL bermuatan karakter melalui icebreaker dapat meningkatkan motivasi belajar bahasa Indonesia materi menulis karangan deskripsi bagi peserta didik Kelas IV SD Negeri Sukoharjo 04 semester II tahun pelajaran 2016/ 2017. Hal ini dapat diketahui dari adanya peningkatan motivasi belajar peserta didik dari kondisi awal ke siklus II dari kategori rendah menjadi tinggi. terdapat peningkatan nilai ratarata motivasi belajar sebanyak 37 .

Tabel 1.Motivasi Belajar Peserta Didik Antar Siklus

\begin{tabular}{cccc}
\hline No & Aspek & Siklus I & Siklus II \\
\hline 1 & Cukup Tinggi & $42,9 \%$ & -
\end{tabular}




\begin{tabular}{clcc}
2 & Tinggi & $57,1 \%$ & $52,4 \%$ \\
3 & Tinggi Sekali & - & $47,6 \%$ \\
4 & Nilai Rata-Rata & 81 & 97 \\
\hline
\end{tabular}

Adapun motivasi setiap siklus dapat digambarkan pada gambar 2 berikut;

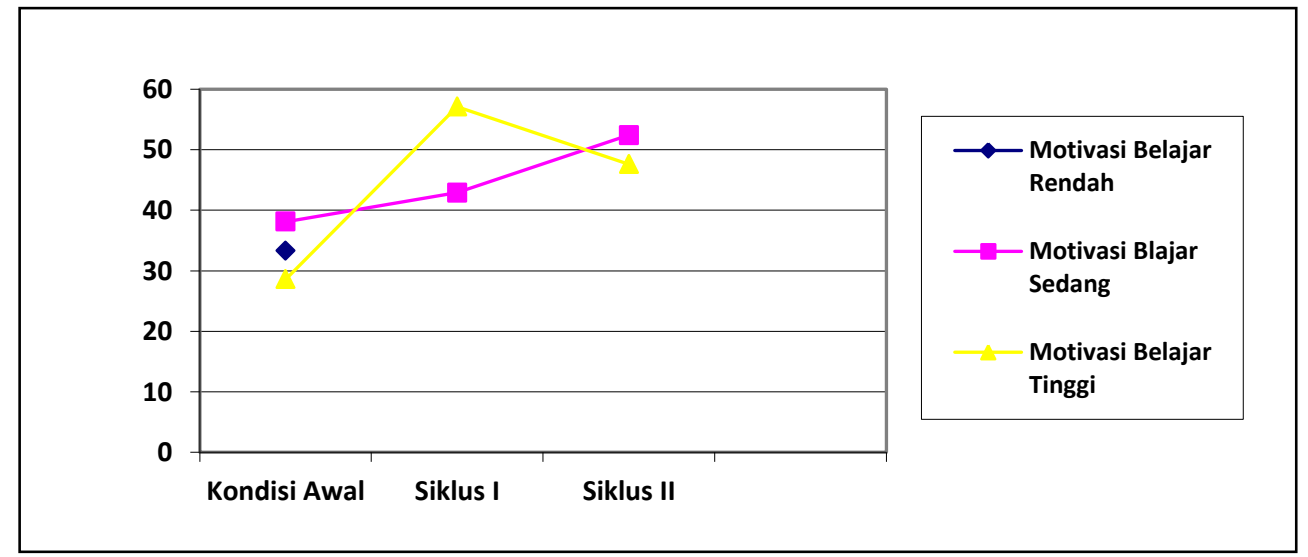

Gambar 2. Motivasi Belajar Peserta Didik Antar Siklus

2) Hasil Perubahan Perilaku Peserta Didik Antar Siklus

Tabel 2 menunjukkan bahwa dengan penerapan strategi pembelajaran CTL bermuatan karakter melalui icebreaker pada pembelajaran bahasa Indonesia materi menulis karangan deskripsi peserta didik Kelas IV SD Negeri Sukoharjo 04 semester II tahun pelajaran 2016/2017, ada perubahan perilaku peserta didik dari kondisi awal ke siklus II terjadi perubahan dari rata-rata nilai 1,52 kategori belum terlihat berubah menjadi nilai rata-ratanya 3,46 dalam kategori mulai berkembang terjadi perubahan 1,94 .

Tabel 2.Hasil Perubahan Perilaku Peserta Didik Antar Siklus

\begin{tabular}{lcccc}
\hline \multirow{2}{*}{ Aspek } & \multicolumn{2}{c}{ Siklus I } & \multicolumn{2}{c}{ Siklus II } \\
\cline { 2 - 5 } & Rata-rata & Kategori & Rata-rata & Kategori \\
\hline Kerja keras & 2,8 & Mulai terlihat & 3,25 & Mulai berkembang \\
Rasa ingin tahu & 2,9 & Mulai terlihat & 3,66 & Mulai berkembang \\
Kreatif & 2,66 & Mulai terlihat & 3,40 & Mulai berkembang \\
Mandiri & 2,57 & Mulai terlihat & 3,40 & Mulai berkembang \\
Tanggung Jawab & 2,66 & Mulai terlihat & 3,40 & Mulai berkembang
\end{tabular}




\begin{tabular}{ccccc}
$\begin{array}{l}\text { Peduli lingkungan } \\
\text { sekitar }\end{array}$ & 2,76 & Mulai terlihat & 3,66 & Mulai berkembang \\
\hline Jumlah & 13,69 & & \\
Rata-rata & 2,73 & Mulai terlihat & 3,46 & Mulai berkembang \\
\hline \multicolumn{4}{l}{ Adapun penyajian perubahan perilaku peserta didik dalam bentuk grafik }
\end{tabular}

dapat dilihat di bawah ini :

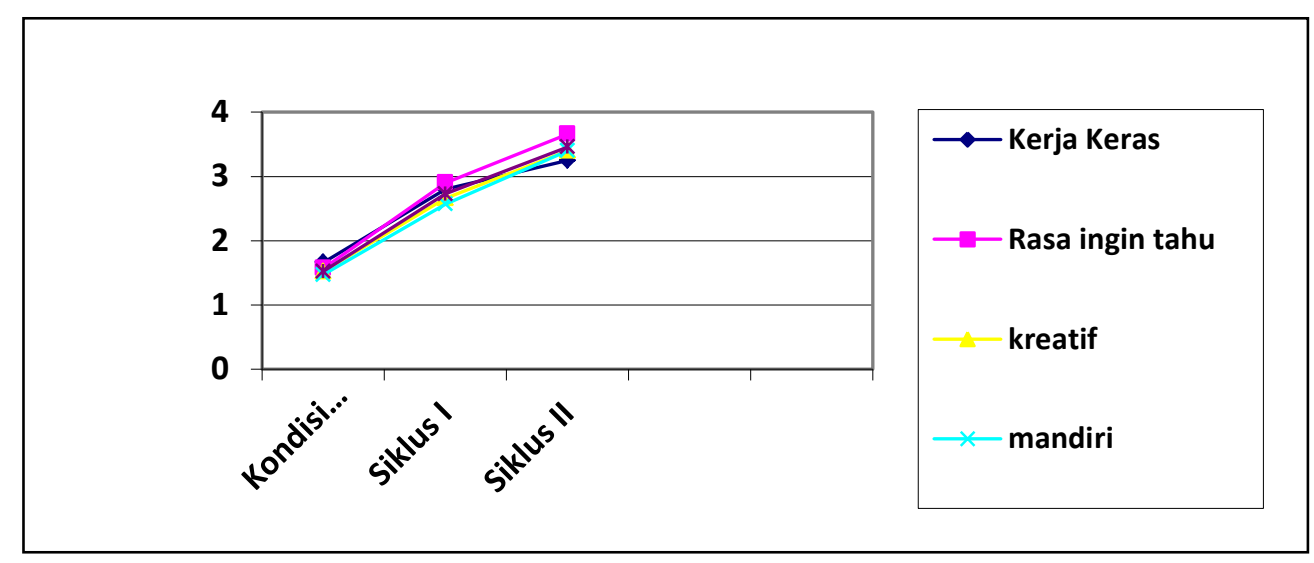

Gambar 3. Motivasi Belajar Peserta Didik Antar Siklus

3) Hasil Observasi Proses Pembelajaran Guru Antar Siklus

Tabel 3.Hasil Observasi Proses Pembelajaran Guru Antar Siklus

\begin{tabular}{lcc}
\multicolumn{1}{c}{ Aspek } & Siklus I & Siklus II \\
\hline Keterampilan membuka pelajaran & 18 & 17 \\
Keterampilan menjelaskan materi pelajaran & 16 & 23 \\
& & \\
Ketermpilan memotivasi peserta didik & 12 & 21 \\
Keterampilan menutup pelajaran & 16 & 21 \\
\hline Nilai Akhir & 72,82 & 95 \\
\hline
\end{tabular}

Berdasarkan tabel di atas Hasil Observasi proses pembelajaran dari siklus I ke siklus ke dua terjadi peningkatan dari nilai akhir 72,82 meningkat 95 terjadi peningkatan sebesar 22,18. Sedangkan peningkatan Hasil Mengarang Peserta Didik Antar Siklus 
Tabel 4.Data Hasil Karangan Antar Siklus

\begin{tabular}{|c|c|c|c|c|c|c|c|}
\hline \multirow{2}{*}{ No } & \multirow{2}{*}{ Ketuntasan } & \multicolumn{2}{|c|}{ Kondisi Awal } & \multicolumn{2}{|c|}{ Siklus I } & \multicolumn{2}{|c|}{ Siklus II } \\
\hline & & Jumlah & $\%$ & Jumlah & $\%$ & Jumlah & $\%$ \\
\hline 1. & Tuntas & 4 & 19,00 & 15 & 81,40 & 21 & 100 \\
\hline 2. & Belum Tuntas & 17 & 81,00 & 6 & 28,60 & 0 & 0 \\
\hline \multicolumn{2}{|c|}{ Jumlah } & 21 & 100 & 21 & 100 & 21 & 100 \\
\hline \multicolumn{2}{|c|}{ Nilai Rata-rata } & \multicolumn{2}{|c|}{57,40} & \multicolumn{2}{|c|}{68,80} & \multicolumn{2}{|c|}{76,43} \\
\hline \multicolumn{2}{|c|}{ Nilai Tertinggi } & \multicolumn{2}{|c|}{70,00} & \multicolumn{2}{|c|}{80,00} & \multicolumn{2}{|c|}{85,00} \\
\hline \multicolumn{2}{|c|}{ Nilai Terendah } & \multicolumn{2}{|c|}{45,00} & \multicolumn{2}{|c|}{60,00} & \multicolumn{2}{|c|}{70,00} \\
\hline
\end{tabular}

Tabel 4 di atas menunjukkan bahwa dengan penerapan strategi pembelajaran CTL bermuatan karakter dapat meningkatkan hasil belajar bahasa Indonesia materi menulis karangan deskripsi bagi peserta didik Kelas IV SD Negeri Sukoharjo 04 semester II tahun pelajaran 2016/2017. Hal ini dapat diketahui adanya peningkatan prosentase ketuntasan peserta didik dan nilai ratarata kelas pada siklus II mendapatkan nilai melebihi indikator keberhasilan yang telah ditetapkan sebelumnya (Persentase ketuntasan: 78\% dengan Rata-rata kelas: $65,00)$.

Ada peningkatan nilai ketuntasan peserta didik dari 4 peserta didik (19\%) meningkat menjadi 21 peserta didik $(100 \%$ > indikator keberhasilan $78 \%)$, bertambah 17 peserta didik (81\%). Nilai rata-rata kelas dari 57,38 menjadi 76,43 (>indikator keberhasilan 65), meningkat 19,05.

\section{b. Pembahasan}

Berdasarkan penelitian tindakan kelas dengan menerapkan strategi pembelajaran CTL bermuatan karakter untuk meningkatkan motivasi dan hasil 
belajar menulis karangan deskripsi pada peserta didik kelas IV SD Negeri Sukoharjo 04 Kabupaten Sukoharjo semester II tahun pelajaran 2016/ 2017 terdapat peningkatan.

Hasil penelitian tindakan kelas melalui strategi pembelajaran CTL bermuatan karakter terdapat peningkatan motivasi belajar peserta didik kelas IV SD Negeri Sukoharjo 04 Kabupaten Sukoharjo semester II tahun pelajaran 2016/ 2017. Peningkatan motivasi belajar peserta didik dari kondisi awal ke siklus II dari kategori rendah menjadi tinggi. terdapat peningkatan nilai rata-rata motivasi belajar sebanyak 37 .

Hasil penelitian tindakan kelas melalui strategi pembelajaran CTL bermuatan karakter ada perubahan perilaku peserta didik kelas IV SD Negeri Sukoharjo 04 Kabupaten Sukoharjo semester II tahun pelajaran 2016/ 2017. ada perubahan perilaku peserta didik_dari kondisi awal ke siklus II terjadi perubahan dari rata-rata nilai 1,52 kategori belum terlihat berubah menjadi nilai rata-ratanya 3,46 dalam kategori mulai berkembang terjadi perubahan 1,94.

Hasil penelitian kelas melalui penerapan strategi pembelajaran CTL bermuatan karakter terdapat peningkatan hasil belajar bahasa Indonesia materi menulis karangan deskripsi bagi peserta didik Kelas IV SD Negeri Sukoharjo 04 semester II tahun pelajaran 2016/2017. Hal ini dapat diketahui adanya peningkatan prosentase ketuntasan nilai ketuntasan peserta didik dari 4 peserta didik (19\%) meningkat menjadi 21 peserta didik (100\% > indikator keberhasilan $78 \%$ ), bertambah 17 peserta didik (81\%). Nilai rata-rata kelas dari 57,38 menjadi 76,43 telah melampui indikator keberhasilan 65, meningkat 19,05.

\section{SIMPULAN}

Berdasarkan hasil penelitian tindakan kelas dengan penerapan strategi pembelajaran CTL bermuatan karakter pada peserta didik Kelas IV SD Negeri Sukoharjo 04 Sukoharjo Semester II tahun pelajaran 2016/ 2017, dapat disimpulkan sebagai berikut.Penerapan strategi pembelajaran CTL bermuatan karakter dapat meningkatkan motivasi belajar menulis karangan deskripsi pada 
peserta didik Kelas IV SD Negeri Sukoharjo 04 Sukoharjo semester II tahun pelajaran 2016/ 2017. Ada peningkatan motivasi belajar peserta didik dari kondisi awal ke siklus II dari kategori rendah menjadi tinggi, terdapat peningkatan nilai rata-rata motivasi belajar sebanyak 37. Melalui penerapan strategi pembelajaran CTL bermuatan karakter dapat merubah perilaku dari mulai terlihat berubah menjadi berkembang peserta didik kelas IV SD Negeri Sukoharjo 04Sukoharjo semester II tahun pelajaran 2016/2017. Penerapan strategi pembelajaran CTL bermuatan karakter dapat meningkatkan hasil belajar menulis karangan deskripsi pada peserta didik Kelas IV SD Negeri Sukoharjo 04 Kabupaten Sukoharjo semester II tahun pelajaran 2016/2017. Ada peningkatan nilai ketuntasan peserta didik dari 4 peserta didik (19\%) meningkat menjadi 21 peserta didik (100\%) bertambah 17 peserta didik (81\%). Nilai rata-rata kelas dari 57,4 menjadi 76,43, meningkat 19,03 .

\section{DAFTAR PUSTAKA}

Abdullah, Ridwan Sani. 2015. Inovasi Pembelajaran. Jakarta:Bumi Aksara.

Ahmadi,lif, Khiri. 2011. PAIKEM GEMBROT. Jakarta: Prestasi Pustaka.

Anitah, Sri. 2008. Strategi Pembelajaran di SD. Jakarta: Universitas Terbuka.

Amri, Sofan. 2013. Pengembangan dan Model Pembelajaran dam Kurikulum 2013. Jakarta: PT. Prestasi Pustakaraya

Daryanto. 2012. Model Pembelajaran Inovatif. Yogyakarta:Gava Media.

Daryanto. 2015. Teori Belajar dan Proses Pembelajaran Yang Mendidik. Yogyakarta :Gava Media.

Ismawati, Isti. 2011. Perencanaan Pengajaran Bahasa dan Sastra Indonesia. Surakarta : Yama Pustaka

Keraf, Gorys. 1982. Eksposisi dan Deskripsi. Ende Flores: Nusa Indah.

Muslich, Mansur. 2009. KTSP Pembelajaran Berbasis Kompetensi dan. Kontekstual. Jakarta: Bumi Aksara 
Nurgiyantoro, Burhan. 2011. Penilaian Pembelajaran Bahasa Indonesia Berbasis Kompetensi. Yogyakarta: BPFE.

Rohmadi,Muhammad.Subiyantoro Slamet. 2009. Bunga Rampai Model-model Pembelajaran Bahasa, Sastra, dan Seni. Surakarta:Yuma Pustaka

Sudjana, Nana. 2002. Penilaian Hasil Proses Belajar Mengajar. Bandung: PT. Remaja Rosdakarya. . 2010. Penilaian Hasil Proses Belajar Mengajar. Bandung: PT Remaja Rosdakarya.

Sunarto. 2012. Icebreaker dalam Pembelajaran Aktif. Surakarta:Cakrawa Media.

Suparno. 2008. Keterampilan Dasar Menulis. Jakarta: Universitas Terbuka.

Suprijono, Agus. 2009. Cooperative Learning. Yogyakarta: Pustaka Pelajar.

Suyadi. 2013. Strategi Pembelajaran Pendidikan Karakter. Bandung: PT. Remaja Rosdakarya.

Tarigan, Henry Guntur. 2008. Menulis: sebagai Suatu Keterampilan Berbahasa. Bandung: Angkasa.

Widiasworo, Erwin. 2017. Masalah-Masalah Peserta Didik Dalam Kelas dan Solusinya. Yogyakarta: Araska.

Widoyoko, E.P. 2012. Teknik Penyusunan Instrumen penelitian. Yogyakarta: Pustaka Pelajar.

Yamin. 2007. Kiat Membelajarkan Siswa. Jakarta: Gaung Persada Press 